Kurzreferate - Communication

Tuberkulose 1953;10:255

\title{
Zur Segmentresektion bei Lungentuberkulose
}

A.P.

Naef

Lausanne

Das Referat erschien in extenso in «Praxis» 42, 394-398, 1953 